\title{
Many New Voters Make the Granite State One to Watch in November
}

\author{
KENNETH M. JOHNSON, DANTE SCALA, AND ANDREW SMITH
}

$\mathrm{N}$ ew Hampshire is an increasingly mobile state, with considerable turnover of its residents. This turnover is changing the voter base in the state with potentially dramatic implications for the November elections. Nearly a third of the potential voters in New Hampshire this November became eligible to vote in the past eight years. These potential new voters are more likely to identify with the Democratic Party than are established New Hampshire voters.

\section{Demographic Trends}

Migration plays a critical role in shaping the electorate of New Hampshire. The state has one of the most mobile populations in the nation. Fewer than 45 percent of the residents of New Hampshire were born in the state. In contrast, nationwide 67 percent of the native-born population resides in the state in which they were born. Only five states have a smaller proportion of their nativeborn population still living in their state of birth.

Between 2000 and 2008, an estimated 321,000 people moved to New Hampshire from elsewhere in the United States. Some subsequently left the state, but most remained. We estimate that 208,000 of these migrants who are U.S. citizens of voting age remain in the state. During the same period, an estimated 292,000 people left the state. Some subsequently returned but most did not. We estimate that 199,000 of those who left and have not returned were citizens of voting age. In all, as many as 407,000 potential voters moved in or out of New Hampshire during those eight years, a substantial change for a state with an electorate of only 991,000 .

The largest source of new migrants to New Hampshire is the Boston metropolitan area according to prior Carsey Institute research. New Hampshire also gains significant numbers of migrants from the Northeast and the South. Migrants to New Hampshire include many families with children that settle in the state's urban and suburban southern region as well as 50-69 year-olds who relocate to the state's recreational and amenity areas.

A second demographic force influencing the electorate is life cycle changes among its population. Between 2000 and 2008, 113,000 New Hampshire citizens celebrated their 18th birthday. However, the voter pool was thinned by the deaths of 83,000 New Hampshire residents.

Together the migrants and those turning 18 in the past eight years represent 321,000 potential new voters or about one-third of the residents eligible to vote this fall (Figure 1). Some will not register or vote, but those who do represent a substantial proportion of those casting ballots. Comparing these new residents with the established population of the state demonstrates how demographic change may affect the upcoming election.

Figure 1. Estimated Young, Migrant, and Established Potential Voters in New Hampshire, 2008

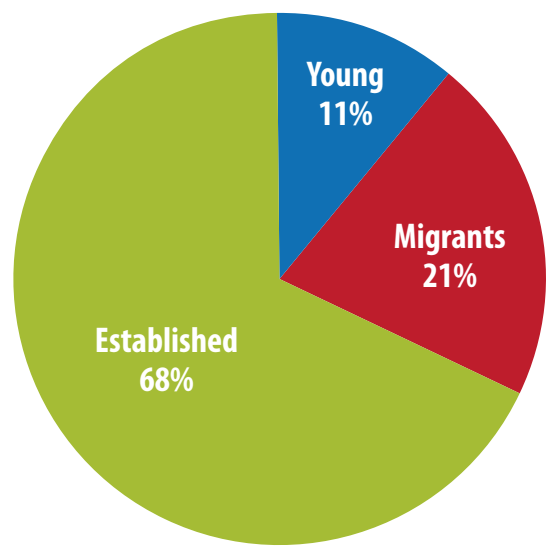

Estimated Potential Voters $=991,000$

Analysis: K. M. Johnson, Carsey Institute, University of New Hampshire Source: Census Bureau and Internal Revenue Service 
Figure 2: Party Identification of Young Voters, Migrants, ANd Established Voters

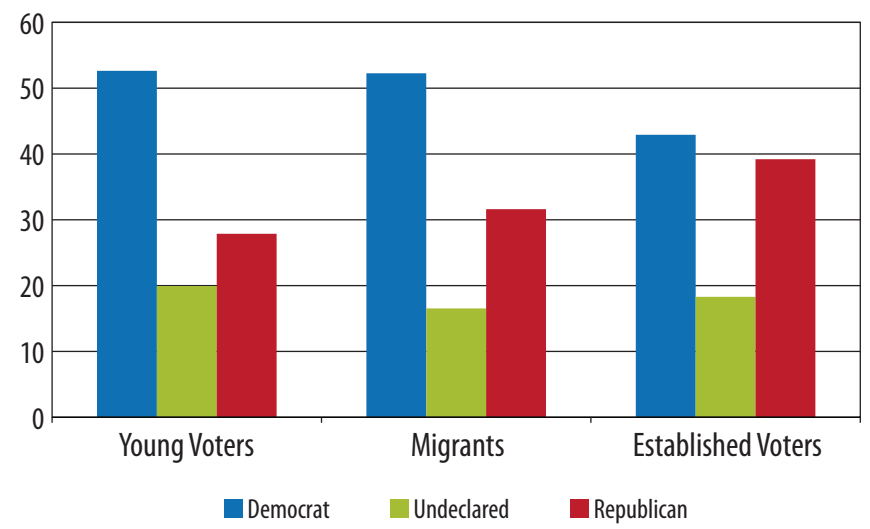

Analysis: K. M. Johnson, Carsey Institute, University of New Hampshire Source: Granite State Polls, University of New Hampshire

\section{New Voters More Likely to Identify as Democrats}

The influx of potential voters to New Hampshire has significant implications because they differ in their party identification from long-time residents. We divide the potential voters into three groups. Young potential voters are residents who are citizens and turned 18 after 2000. Migrants are potential voters who have moved to New Hampshire from elsewhere in the United States since 2000. Established potential voters are eligible voters who resided in New Hampshire in both 2000 and 2008.

Both young voters (53 percent) and migrants (52 percent) are more likely to identify as Democrats than are established voters (43 percent), according to analysis of the University of New Hampshire Survey Center's Granite State Polls (Figure 2). In contrast, 39 percent of the established voters identify with the Republican Party compared with 28 percent of the young voters and 32 percent of the migrants. Young voters are also slightly more likely to identify as undeclared than are either migrants or established voters.

Although stated preferences of new potential voters differ from those of established residents, this has yet to be fully reflected in voter registration data. For example, only 17 percent of young voters are registered as Democrats, yet 53 percent identify themselves as such (Figure 3 ). Similarly, the 12 percent of young potential voters who have registered as Republicans is considerably less than the 28 percent who identify as Republicans. Young voters are also the least likely to have registered, and among those who have, most registered as undeclared. The trends are similar among migrants. Fewer than 25 percent have registered as Democrats and 16 percent as Republicans, although many more identify with each party. Nearly 40 percent are registered as undeclared and 19 percent are not registered. Established potential voters are the most likely to be registered and although many register as undeclared, they are also the most likely to have a party affiliation. Among those who are registered, 24 percent registered as Democrats and 27 percent as Republicans.

Differences among the potential voter groups may result from differences in key demographic indicators. Migrants to New Hampshire are both better educated and earn higher incomes than do established or new voters. Nearly 65 percent of the migrants hold at least a bachelor's degree and 38 percent have household incomes of $\$ 100,000$ or more. In comparison, 52 percent of the established group has at least a bachelor's degree, and 29 percent have household incomes of more than $\$ 100,000$. As would be expected, younger voters have lower levels of education (29 percent have at least a bachelor's degree) and lower incomes (15 percent of young households have incomes over $\$ 100,000)$ than their older and more experienced colleagues.

Where the three voting groups reside also differs, with implications for the election. Most recent migrants to New Hampshire are clustered near the Massachusetts border on the periphery of the Boston metropolitan area, in the Seacoast region, or in the Connecticut Valley. Many new voters also reside in the suburban region near the Massachusetts border and Seacoast, but Manchester is also popular among the younger group. Established voters cluster in the same Massachusetts suburban border region, along the Seacoast, and also in the Central/Lake regions.

Figure 3: Voter Registration of Young Voters, Migrants, ANd Established Voters

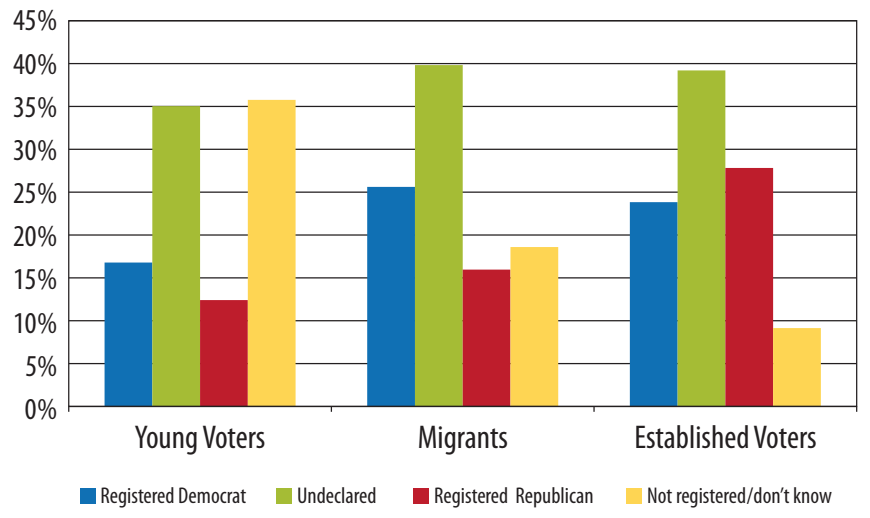

Analysis: K. M. Johnson, Carsey Institute, University of New Hampshire Source: Granite State Polls, University of New Hampshire 
Figure 4: Change in Democratic and Republican Registration and in Net Migration for New Hampshire Counties

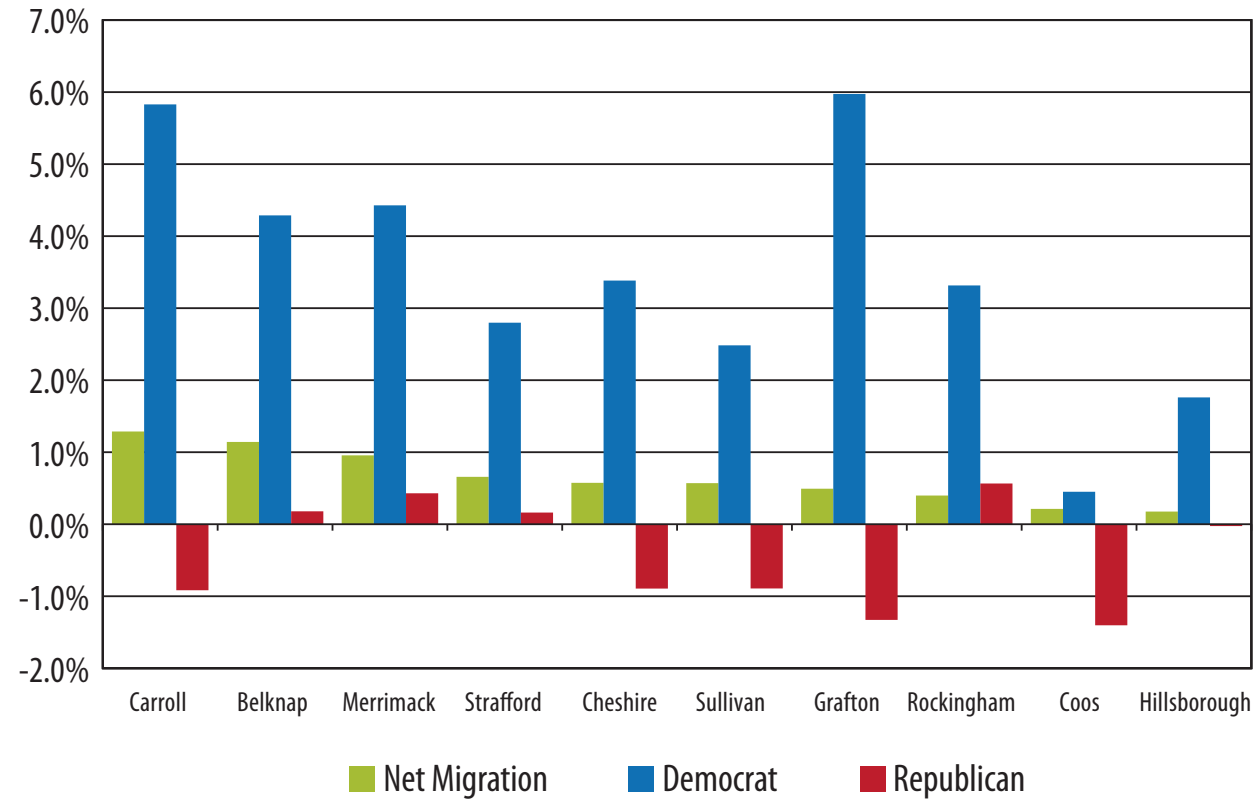

Analysis: Dante Scala, University of New Hampshire

Source: New Hampshire Secretary of State and Census Bureau

\section{Changing Patterns of Voter Registration}

The impact of changing demographics is reflected in the changing voter registration patterns since the 1990s. After the 1998 election, there were 272,000 registered Republicans in New Hampshire and 203,000 registered Democrats, a difference of 70,000. Ten years later, the difference had narrowed to 6,000 more registered Republicans $(271,000)$ than Democrats $(265,000)$. Thus, Democratic registrations grew by 30 percent, between 1998 and 2008, while Republican registrations remained stable. Statewide voter registration grew by 14 percent overall.

In general, New Hampshire counties with greater net migration gains experienced larger gains in Democratic registrations. The relationship between migration and Republican registration trends is more complicated, but generally smaller migration gains are correlated with smaller gains or larger losses in Republican registrations.

Hillsborough and Rockingham counties, where half of Granite State residents live, each had modest migration and Democratic registrations gains, but both were below statewide Democratic growth (Figure 4). In contrast, Republican gains remained stagnant in Hillsborough, as they did statewide. Republican registrations did grow modestly in Rockingham County, in part, due to the composition of migration stream into the county. More Republicans were in this migration stream than in those flowing into most other areas of the state, according to Granite State poll data.

The most dramatic changes in partisanship took place in traditionally Republican counties such as Grafton, Carroll, and Belknap. The share of Democrats in these counties grew at nearly twice the statewide Democratic growth rate, in part because the base was small to begin with. Such rapid gains also coincided with large migration gains in Carroll and Belknap counties, suggesting that voter turnover may have contributed to these Democratic gains. Grafton's migration gains were more modest, but its Democratic gains were substantial, suggesting that more subtle demographic forces and other factors were at work. The link between migration (which reflects population turnover) and registration trends gains further credence when examining Republican registration losses. Carroll and Grafton experienced the second and third largest declines in Republican registrations despite significant migration gains. Only Coos County, which experienced little migration gain, experienced a larger Republican loss.

The growing number of Democratic and stable number of Republican registered voters has changed the proportions of each party in counties across the state. Most of these changes in voter partisanship occurred outside the major urban and suburban areas in Rockingham and Hillsborough Counties (Figure 5). For example, Republican registrations declined modestly from 35 to 33 percent in Rockingham County and from 37 to 32 percent in Hillsborough County while Demo- 
Figure 5: Share of New Hampshire Registered Voters by Political Party, 1998 and 2008

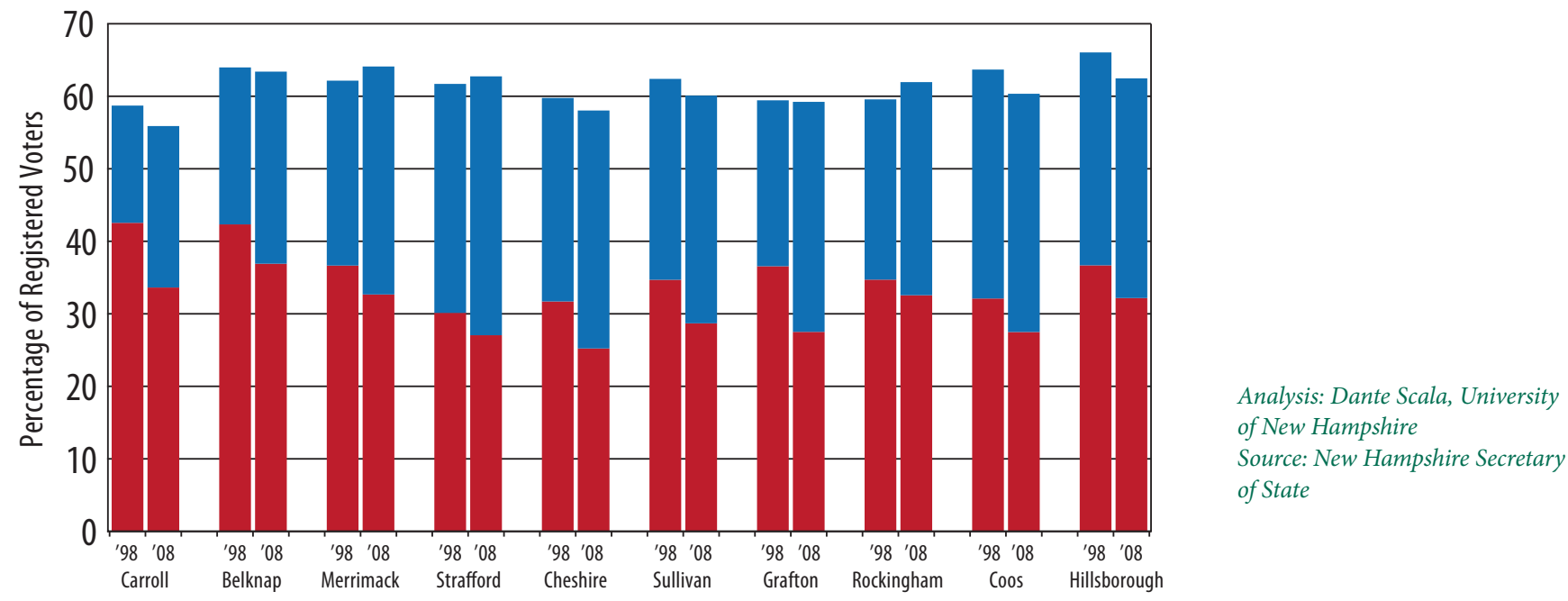

Democrat $\quad$ Republican

cratic registration rose slightly from 25 to 29 percent and 29 to 30 percent, respectively. The proportion undeclared, which is the difference between the party registrations and 100 percent increased slightly in Hillsborough County and declined slightly in Rockingham County. For the other half of the state's voters who live in the eight least populated counties, Democratic registrations increased rapidly while Republican registrations decreased. For example, Democratic registrations rose from 16 to 22 percent in Carroll County and from 23 to 32 percent in Grafton County, while Republican registrations diminished from 43 to 34 percent in Carroll County and from 37 to 28 percent in Grafton County. These Republican losses occurred despite population gains in both counties between 2000 and 2008. Detailed analysis suggests that diminished Republican dominance in these traditional Yankee Republican counties may well be due, at least in part, to the turnover in the pool of voters fueled by migration and generation changes.

\section{Conclusion}

The voting population of New Hampshire is among the most mobile in the United States. About one-third of the potential voters are new to the state's electoral process since 2000. Both young voters and recent migrants are more likely to identify themselves as Democrats and less likely to identify with Republicans than are established voters. Voter turnover fueled by demographic change is also affecting voter registration, with a growing Democratic base and stable or declining numbers of registered Republicans. We conclude that demographic change has significant implications for the November election.

\section{About this Brief}

Kenneth M. Johnson is senior demographer at the Carsey Institute and a professor of sociology at the University of New Hampshire. Dante Scala is an associate professor and Chair of the Political Science Department at the University of New Hampshire. Andrew Smith directs the Survey Center at the University of New Hampshire, where he is also an associate professor of political science. Skye MacKay and Allison Churilla of the Carsey Institute provided valuable research assistance on the project.

Demographic data for this study comes from the U.S. Census Bureau and from the county to county migration series of the Internal Revenue Service. The migration estimates derived from the IRS data should be interpreted with caution. Although IRS data is comprehensive, those who do not file returns or are filing their first return are excluded from the migration analysis. Also, an unknown number of in-migrants to New Hampshire during the study period left the state by 2008 . The overall impact of these factors is unknown because little research exists on the topic, but our models assumed the effect is modest. 
For more detailed analysis of recent demographic trends in New Hampshire and a detailed discussion of methods, see the Carsey Institute Report, The Changing Faces of New Hampshire: Recent Demographic Trends in the Granite State available at www.carseyinstitute.unh.edu.

The Granite State Poll is a quarterly survey of 500 randomly selected New Hampshire adults conducted by telephone. The sample is drawn using random digit dialing so each household in New Hampshire has an equal probability of selection. For this research, data from the Granite State Polls from Fall 2005 to Fall 2008 were combined. The weighted sample size from these polls is 8,300 . Data on migration were only available in the polls from Winter 2007 to Fall 2008.

Voter registration data come from the New Hampshire Secretary of State. These data are reported for November of 1998 and September of 2008. Net migration data used for analysis of voter registration trends are from the Federal State Cooperative Population Estimates Series and cover the period from April 2000 to July 2007. Net migration includes migrants between New Hampshire counties as well as migrants from outside the state. 


\section{CARSEY}

Building knowledge for families and communities

The Carsey Institute at the University of New Hampshire conducts independent, interdisciplinary research and communicates its findings to policymakers, practitioners and the general public.

Huddleston Hall

73 Main Street

Durham, NH 03824

(603) $862-2821$

www.carseyinstitute.unh.edu 